\title{
Regulation of ERa-mediated transcription of Bcl-2 by PI3K-AKT crosstalk: Implications for breast cancer cell survival
}

\author{
MELYSSA R. BRATTON ${ }^{1,2 *}$, BICH N. DUONG ${ }^{3 *}$, STEVEN ELLIOTT ${ }^{2,4}$, CHRISTOPHER B. WELDON $^{5}$, \\ BARBARA S. BECKMAN ${ }^{1,2,7}$, JOHN A. McLACHLAN ${ }^{1,2,7}$ and MATTHEW E. BUROW ${ }^{1,2,4,6}$
}

\author{
${ }^{1}$ Tulane University School of Medicine, Department of Pharmacology, 1430 Tulane Ave.; ${ }^{2}$ Tulane/Xavier Center for \\ Bioenvironmental Research, Health \& Environmental Research Bldg, 1324 Tulane Ave., SL-3, New Orleans, LA 70112; \\ ${ }^{3}$ University of Illinois at Chicago, Department of Anatomy and Cell Biology, 808 S Wood St., Rm 578 M/C 512, Chicago, \\ IL 60612; ${ }^{4}$ Tulane University School of Medicine, Department of Medicine, Hematology/Oncology Section, SL-78, \\ 1430 Tulane Ave., New Orleans, LA 70112; ${ }^{5}$ Department of Surgery, Children's Hospital Boston, 300 Longwood Ave., \\ Boston, MA 02115; ${ }^{6}$ Tulane Cancer Center, 1430 Tulane Avenue, SL-68, New Orleans, LA 70112; \\ ${ }^{7}$ Department of Environmental Health Sciences, Tulane University School of Public Health \\ and Tropical Medicine, 1440 Canal St., New Orleans, LA 70112, USA
}

Received April 15, 2010; Accepted May 21, 2010

DOI: 10.3892/ijo_00000703

\begin{abstract}
Both estrogen, through the estrogen receptor (ER), and growth factors, through the phosphatidylinositol-3-kinase (PI3K)-AKT pathway, have been shown to independently promote cell survival. Here, we investigated the role of ER/ PI3K-AKT crosstalk in the regulation of cell survival in MCF-7 breast carcinoma cells. The ER inhibitor ICI 182,780 was used to determine the requirement of the ER for estrogen in the suppression of tumor necrosis factor- $\alpha(\mathrm{TNF} \alpha)$ induced apoptosis. Gene reporter assays and Western blot analyses were used to determine the involvement of the pro-survival factor Bcl-2 and the coactivator GRIP1 in this survival crosstalk. We demonstrated that an intact ER signaling pathway was required for estrogen to suppress apoptosis induced by $\mathrm{TNF} \alpha$. Our gene reporter assays revealed that ER $\alpha$, not ERß, was targeted by AKT, resulting in transcriptional potentiation of the full-length $\mathrm{Bcl}-2$ promoter, ultimately leading to increased $\mathrm{Bcl}-2$ protein levels. AKT targeted both activation function (AF) domains of the ER $\alpha$ for maximal induction of Bcl-2 reporter activity, although the AF-II domain was predominately targeted. In addition, AKT also caused an upregulation of GRIP1 protein levels. Finally, AKT and GRIP1 cooperated to increase $\mathrm{Bcl}-2$ protein expression to a greater
\end{abstract}

Correspondence to: Dr Matthew E. Burow, Department of Medicine, Tulane University Health Sciences Center, 1430 Tulane Ave. SL-83, New Orleans, LA 70112, USA

E-mail: mburow@tulane.edu

${ }^{*}$ Contributed equally

Key words: estrogen receptor, breast cancer, AKT, cell signaling, cell survival level than either factor alone. Collectively, our study suggests a role for ER/PI3K-AKT crosstalk in cell survival and documents the ability of AKT to regulate Bcl-2 expression via differential activation of ER $\alpha$ and ERß as well as regulation of GRIP1.

\section{Introduction}

Homeostasis in normal breast tissue is maintained by a balance between cell survival and cell death (1). Hence, disregulation of this homeostasis in favor of cell survival can lead to cell proliferation and cancer (2). Estrogen $\left(E_{2}\right)$ is an endogenous factor that plays a critical role in normal mammary functions (3). However, $\mathrm{E}_{2}$ has been implicated in breast cancer due to its pro-survival effects $(4,5)$. The phorbol ester insulin-like growth factor 1 (IGF-1), is also involved in cell survival and its effects are largely mediated by the phosphatidylinositol 3 kinase (PI3K)-AKT signaling cascade (6). While there are many downstream targets of PI3K, the serine/threonine kinase AKT is the primary mediator of PI3K survival signaling due to AKT's ability to regulate cellular components that affect cell survival decisions, such as Bad and Forkhead transcription factors (7).

The actions of $\mathrm{E}_{2}$ are mediated by the estrogen receptor (ER). The two isoforms of the ER, ER $\alpha$ and ERß, belong to the steroid/thyroid hormone superfamily of nuclear receptors that function as ligand-activated transcription factors (8). Transcriptional activities of the receptors are mediated by two distinct activation function (AF) domains: the AF-I domain in the amino terminus exhibits constitutive ligandindependent activity, and the AF-II domain in the carboxyterminus requires ligand binding for activity (9). To achieve full transcription potential, the ER must also recruit histone modifying coactivators to overcome the steric hindrances imposed on tightly packed chromatin $(10,11)$. Glucocorticoid receptor-interacting protein 1 (GRIP1), a member of the p160 
family of coactivators, has been shown to interact with both AF domains of the ER (12-14), increasing the transcriptional activity of the receptor (15). Several coactivators have been implicated in breast cancer etiology (16-18), and researchers have recently begun to study peptide growth factor regulation of coactivator function to better understand cancer development (19-21).

Both $\mathrm{E}_{2}$ (22-24) and IGF-1 (25-27) enhance cancer cell survival in part through their abilities to upregulate Bcl-2 expression. A cAMP response element (CRE) within the Bcl-2 promoter is targeted by IGF-1 signaling via AKT phosphorylation of the cAMP response element binding protein (CREB) $(26,27)$. Likewise, the ER has been shown to play an integral role in $\mathrm{E}_{2}$ regulation of $\mathrm{Bcl}-2$ expression (28-30). However, the exact role of the ER at the $\mathrm{Bcl}-2$ promoter remains unclear. A survival crosstalk between the ER- $E_{2}$ and IGF1-PI3K-AKT signaling pathways (31-33) may protect cancer cells from apoptosis induced by the chemotherapeutic drug tamoxifen (34) and the microbial product wortmannin (35). In these cases, peptide growth factor activation of the PI3K-AKT signaling cascades potentiated ER $\alpha$ transcriptional activity $(31,33,34)$. Interestingly, the CRE site within the $\mathrm{Bcl}-2$ promoter is flanked by two EREs, making the $\mathrm{Bcl}-2$ promoter a possible point of convergence for this ER-E $E_{2} /$ PI3K-AKT survival crosstalk.

The endogenous cytokine tumor necrosis factor $\alpha(\mathrm{TNF} \alpha)$ has pleiotropic biological functions (36) and is produced by a variety of cell types in both normal (37) and breast cancer tissue (38). TNF $\alpha$ induces apoptosis in normal breast tissue during involution (39) and in breast cancer cells (40). TNF $\alpha$ induced apoptosis is inhibited by Bcl-2 (41). Hence, factors that control Bcl-2 expression may increase cell survival and contribute to breast cancer growth, even in the presence of TNF $\alpha(36,42)$.

Given the roles of estrogen and peptide growth factors in breast cancer biology, we hypothesize that PI3K-AKT-ER $\alpha-\mathrm{E}_{2}$ crosstalk enhances cancer cell survival. We evaluated the ability of ER/PI3K-AKT crosstalk to affect MCF-7 cells at both the biological and molecular levels. Our results indicate that activation of the PI3K-AKT pathway contributes to breast cancer cell survival through transcriptional activation of the Bcl-2 gene product in an ER $\alpha$-dependent manner, which may increase breast cancer cell survival in the presence of TNF $\alpha$ (43). Given the potential of TNF $\alpha$ use in breast cancer therapy $(36,42)$, a mechanistic study of this PI3K-AKT-ER $\alpha-E_{2}$ survival crosstalk was investigated.

\section{Materials and methods}

Reagents. Dulbecco's modified Eagle's medium (DMEM), phenol-red free DMEM, fetal bovine serum (FBS), BME amino acids, MEM amino acids, L-glutamine, penicillin, streptomycin, and sodium pyruvate were obtained from Gibco-BRL (Gaitherburg, MD). Porcine insulin was purchased from Sigma (St. Louis, MO), and charcoal stripped (CS) FBS was obtained from HyClone (Logan, UT). Lipofectamine and Effectene were purchased from Gibco-BRL (Grand Island, NY) and QiaGen (Valencia, CA), respectively. ICI 182,780 was obtained from Tocris (Ellisville, MO). TNF $\alpha$ was obtained from R\&D systems (Minneapolis, MN). 17ß-estradiol $\left(\mathrm{E}_{2}\right)$ and all protease inhibitor cocktails were purchased from Sigma; NuPAGE 4-8\% Bis-Tris gel was obtained from Invitrogen (Carlsbad, CA); Bio-Rad protein assay reagent was purchased from Bio-Rad (Hercules, CA). The primary antibodies, mouse anti-human Bcl-2, rabbit anti-GRIP1, and rabbit anti-actin, were obtained from BD PharMigen (San Diego, CA), Upstate Biotechnology (Lake Placid, NY) and Sigma, respectively. The secondary antibodies, horseradish peroxidase (HRP) conjugated goat anti-mouse and anti-rabbit, were purchased from Transduction Laboratories (Lexington, KY) and Cell Signaling (Beverly, MA), respectively. ECL chemiluminescence system was obtained from Amersham (Buckinghamshire, England), and Biomax film was purchased from Kodak (Rochester, NY). The inverted fluorescence microscope was purchased from Leica (Wetzlar, Germany), and the Monolight 2010 luminometer was obtained from Analytical Luminescence Laboratory (Ann Arbor, MI).

Plasmids. pGL3-Con-Luc, pEGFP-N1, and dominant negative AKT (AKT-DN) were obtained from Promega (Madison, WI), Clontech (Palo Alto, CA), and Upstate Biotechnology, respectively. The following expression vectors have been previously described: constitutive active AKT (AKT-CA) (44), pcDNA3.1-ER $\alpha$ and $\beta$ (45). pRST7-ER $\alpha$ and pRST7-ERß constructs (AF-I with alanine substituting for amino acids at positions 436, 440, and 443; AF-II containing amino acids 90-477) were generously provided by Dr Donald McDonnell (46). Bcl-2-Luciferase reporter construct (-3934 to -1287 basepairs upstream from the transcription start site) was a gift of Dr Martin P. Smith and Dr Linda Boxer (47).

Cell culture. Estrogen receptor positive MCF-7 human breast carcinoma (48) and estrogen receptor negative human embryonic kidney (HEK) 293 cells (49) were maintained in Dulbecco's modified Eagle's medium (DMEM) supplemented with 10\% FBS, BME amino acids, MEM amino acids, Lglutamine, $100 \mathrm{U} / \mathrm{ml}$ penicillin, $100 \mathrm{U} / \mathrm{ml}$ streptomycin, sodium pyruvate, and $1 \times 10^{-10} \mathrm{M}$ porcine insulin under mycoplasma-free conditions at $37^{\circ} \mathrm{C}$ in humidified $5 \% \mathrm{CO}_{2}$ and 95\% air. For described studies, MCF-7 cells were grown for $48 \mathrm{~h}$ in phenol red-free DMEM supplemented with 5\%charcoal stripped (CS) FBS, and supplements as above, but without insulin (5\% CS-DMEM), as previously described (23).

Transient transfection and luciferase assay. MCF-7 and HEK 293 cells were transfected as previously described (23). Briefly, cells were placed in 5\% CS-DMEM for $48 \mathrm{~h}$ prior to plating onto 24 -well plates at $1 \times 10^{4}$ cells/well and allowed to attach overnight. The next day, the cells were transfected for $5 \mathrm{~h}$ in the serum/supplement-free DMEM using either Lipofectamine or Effectene according to the manufacturers' protocols. For reporter-based luciferase assay, MCF-7 and HEK 293 cell were transfected with the reporter (Bcl-2-Luc), along with vector control (Vec), AKT-CA, or AKT-DN, with 293 cells additionally transfected with various ER $\alpha$ or ERß constructs. After $5 \mathrm{~h}$, the transfection medium was replaced with 5\% CS-DMEM, and treated with chemicals (vehicle control or $1 \mathrm{nM} \mathrm{E}_{2}$, with or without $100 \mathrm{nM}$ ICI 182,780). 
After $24 \mathrm{~h}$, the treatment-containing medium was removed and $1 \mathrm{X}$ lysis buffer $(100 \mu \mathrm{l})$ was added per well and gently shaken for $30 \mathrm{~min}$ at room temperature. The cell debris was then pelleted by centrifugation at $15,000 \mathrm{x} g$ for $5 \mathrm{~min}$. Luciferase activity for $30 \mu \mathrm{l}$ of cell extract was determined using luciferase assay substrate in a Monolight 2010 luminometer.

Viability assay. Viability assay using crystal violet (CV) was performed as previously described (44). Briefly, MCF-7 cells $\left(1 \times 10^{4} /\right.$ well $)$ in 24 -well plates with $5 \%$ CS-DMEM were treated with $10 \mathrm{ng} / \mathrm{ml} \mathrm{TNF-} \alpha$, with or without $1 \mathrm{nM} \mathrm{E}_{2}$, with or without $100 \mathrm{nM}$ ICI 182,780 for $24 \mathrm{~h}$, stained using $0.5 \%$ crystal violet $(200 \mu \mathrm{l})$ for $15 \mathrm{~min}$, washed twice with phosphate buffered saline (PBS), lysed in 1\% SDS solution (600 $\mu 1)$, transferred to a 96 well plate, and absorbency (ABS) at $550 \mathrm{~nm}$ was measured. ABS of treated samples was normalized to untreated control (100\%). For reporter gene viability assay, cells were transfected with pGL3-Luc reporter and empty vector (Vec) or constitutive active AKT (AKT-CA), treated for $48 \mathrm{~h}$ with $10 \mathrm{ng} / \mathrm{ml} \mathrm{TNF}-\alpha$, with or without $1 \mathrm{nM} \mathrm{E}$, with or without $100 \mathrm{nM}$ ICI 182,780 and harvested for luciferase assay with data represented as percent viability normalized to untreated control $(100 \% \pm$ SEM). Apoptosis analysis with fluorescence microscopy was performed as previously described (50) with the use of green fluorescence protein (GFP) instead of LacZ as a marker of transfection. Cells were transfected with pEGFP (100 ng) and $500 \mathrm{ng}$ empty vector (Vec) or constitutive active AKT (AKT-CA) using Effectene, followed by treatment with $10 \mathrm{ng} / \mathrm{ml} \mathrm{TNF-} \alpha$, with or without $1 \mathrm{nM} \mathrm{E}_{2}$, with or without $100 \mathrm{nM}$ ICI 182,780 for $24 \mathrm{~h}$, after which cells were fixed in $4 \%$ paraformaldehyde and washed twice with PBS. Apoptotic (rounded) and normal GFP expressing cells were visualized using a Leica inverted fluorescence microscope.

Immunoblot analysis. MCF-7 and HEK 293 cells were seeded at $5 \times 10^{6}$ cells $/ 100 \mathrm{~mm}^{2}$ plate. MCF-7 cells were transfected with a total of $5 \mu \mathrm{g}$ DNA of empty vector (Vec), constitutive active AKT (AKT-CA), or pSG5-GRIP1-HA (GRIP1), or a combination of AKT-CA and pSG5-GRIP1-HA. The 293 cells were additionally transfected with ER $\alpha$. Cell were transfected using Lipofectamine for $5 \mathrm{~h}$, then treated with vehicle control or $1 \mathrm{nM} \mathrm{E}_{2}$ with or without $100 \mathrm{nM} \mathrm{ICI}$ 182,780 for $24 \mathrm{~h}$. Cells were washed twice in $4^{\circ} \mathrm{C} \mathrm{PBS}, \mathrm{pH} 7.2$, harvested in sonicating buffer $(62.5 \mathrm{mM}$ Tris- $\mathrm{HCl}, \mathrm{pH} 6.8$, $4 \% \mathrm{w} / \mathrm{v}$ SDS, $10 \%$ glycerol, $1 \mathrm{mM}$ phenylmethylsulfonyl fluoride (PMSF), $10 \mu \mathrm{l} / \mathrm{ml}$ protease inhibitor cocktail), and sonicated for $30 \mathrm{sec}$ on ice. Following centrifugation at $1,000 \mathrm{x} \mathrm{g}$ for $20 \mathrm{~min}$ and determination of protein concentration using Bio-Rad protein assay, $50 \mu \mathrm{g}$ of protein was resuspended in sample loading buffer $(62.5 \mathrm{M}$ Tris- $\mathrm{HCl}, \mathrm{pH}$ $6.8,2 \% \mathrm{w} / \mathrm{v}$ SDS, $10 \%$ glycerol, $5 \%$ B-mercaptoethanol, $0.01 \%$ bromophenol blue), boiled for $3 \mathrm{~min}$ and electrophoresed onto NuPAGE 4-8\% Bis-Tris gel. The proteins were then transferred electrophoretically to a nitrocellulose membrane, and the membrane was blocked with PBS/0.05\% Tween $/ 5 \%$ low-fat milk solution at $4{ }^{\circ} \mathrm{C}$ overnight with gentle shaking. The membrane was subsequently incubated with $1 \mu \mathrm{g} / \mathrm{ml}$ mouse anti-human Bcl-2 or $4 \mu \mathrm{g} / \mathrm{ml}$ rabbit anti-GRIP1 antibody for $2 \mathrm{~h}$ at room temperature with gentle shaking. The blot was washed in PBS/0.05\% Tween solution and incubated with 1:5,000 dilution of HRP-conjugated goat anti-mouse or 1:2,000 dilution of HRP-conjugated anti-rabbit antibody for $30 \mathrm{~min}$ at room temperature with gentle shaking. Following four washes with PBS/0.05\% Tween solution, immunoreactive proteins were detected using ECL chemiluminescence system and recorded by fluorography on Kodax Biomax film according to the manufacture's instructions. The membrane was then stripped in stripping solution (2\% SDS, $62.5 \mathrm{mM}$ Tris- $\mathrm{HCl}, \mathrm{pH} 6.7,7 \mu \mathrm{l} / \mathrm{ml} \mathrm{B-mercaptoethanol)} \mathrm{for} 12 \mathrm{~min}$ at $60^{\circ} \mathrm{C}$, and the same protocol as above was used to re-probe the membrane with 1:200 dilution of rabbit anti-actin antibody and subsequently with 1:3,000 dilution of anti-rabbit antibody. Fluorograms were quantitated by image densitometry using Quality One program for data acquisition and analysis (BioRad, Hercules, CA).

Statistical analysis. Data were analyzed using one-way analysis of variance (ANOVA) and post-hoc Tukey's multiple comparisons with Origin 7.0 software. Statistically significant changes were determined at the $\mathrm{p}<0.05$ level as indicated for each figure.

\section{Results}

The ER is required for cell survival signaling through AKT. Both estrogen, acting through the ER (51) and peptide growth factors, working through PI3K-AKT (52), can suppress apoptosis induced by various agents. To determine whether the previously described crosstalk between these two signaling pathways (31-35) can protect MCF-7 breast carcinoma cells from apoptosis induced by the endogenous cytokine TNF $\alpha$, cell viability assays were performed. TNF $\alpha(10 \mathrm{ng} / \mathrm{ml})$ caused a significant decrease in MCF-7 cell survival compared to untreated control cells (Fig. 1A). $\mathrm{E}_{2}(1 \mathrm{nM})$ functioned as a potent cell survival signal by elevating cell survival to the levels of untreated control cells $\left(95.2 \pm 4.3 \%\right.$ viability with $\left.\mathrm{E}_{2}\right)$ (Fig. 1A). Not surprisingly, ablation of ER signaling with the pharmacologic inhibitor ICI 182,780 $(1 \mu \mathrm{M})$ abrogated the anti-apoptotic activity of $\mathrm{E}_{2}$.

Since AKT is involved in cell survival, the ability of this kinase to mediate cell survival in the presence of $\mathrm{TNF} \alpha$ was investigated. A viability assay was performed in MCF-7 cells transfected with either empty vector $(\mathrm{Vec})$ or constitutive active AKT (AKT-CA) (Fig. 1B). In the presence of TNF $\alpha$ $(10 \mathrm{ng} / \mathrm{ml})$, AKT-CA elevated cell survival from $55.9 \pm 5.4 \%$ to $95.7 \pm 3.1 \%$. However, AKT protection was reduced to $47.2 \pm 6.3 \%$ in the presence of ICI $182,780(100 \mathrm{nM})$, again suggesting that the ER is required for AKT-mediated cell survival. Cell death was confirmed morphologically with fluorescence microscopy of GFP-transfected cells that were subjected to the same treatments as above (Fig. 1C). These results suggest that the ER is required for reversal of $\mathrm{TNF} \alpha$ induced apoptosis.

The ER is required for potentiation of Bcl-2 expression by $A K T$. The transcriptional activity of the ER is important for cell survival (53), since the receptor upregulates the expression of gene products required for long-term cell survival, such as $\mathrm{Bcl}-2$. Since $\mathrm{E}_{2}$ has been shown to increase $\mathrm{Bcl}-2$ expression 
A

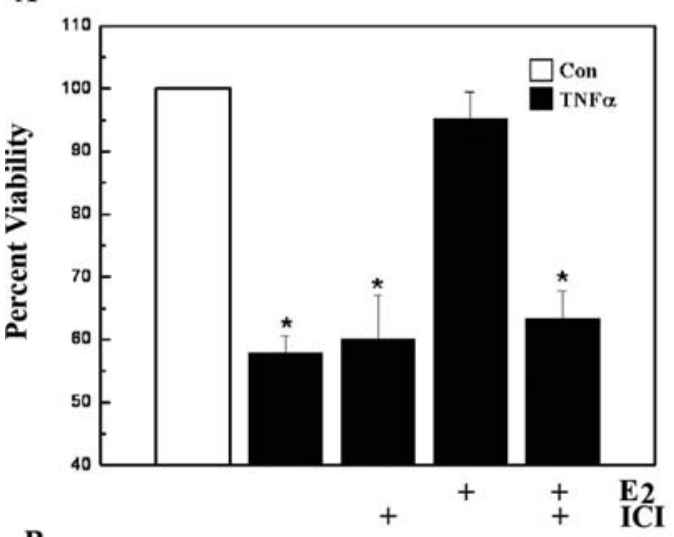

B

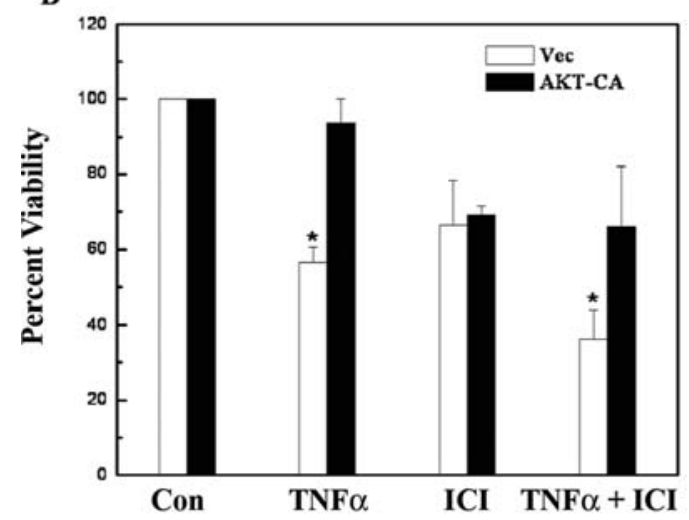

C
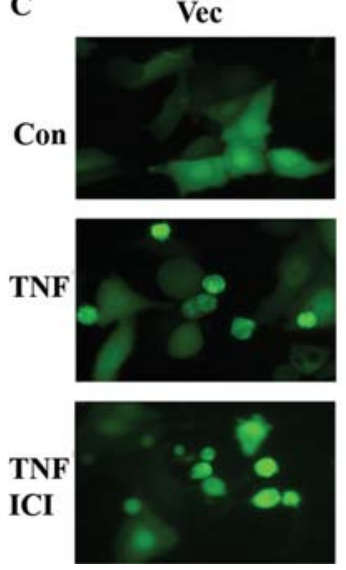

Figure 1. The ER is required for cell survival mediated by signaling through AKT. (A) MCF-7 cells were treated with vehicle control (Con) or $\mathrm{E}_{2}(10 \mathrm{nM})$ in the presence or absence of ICI 182,780 $(100 \mathrm{nM})$ for $24 \mathrm{~h}$ and then exposed to $\mathrm{TNF} \alpha(10 \mathrm{ng} / \mathrm{ml})$. Cells were harvested for $\mathrm{CV}$ viability assay $24 \mathrm{~h}$ later Asterisk denotes statistical significance from control ( $\mathrm{p}<0.05$ ). (B) MCF-7 cells were transfected with $2 \mu \mathrm{g}$ of empty vector (Vec) or constitutive active AKT (AKT-CA) along with pGL3-Luc (200 ng). Cells were treated with vehicle (Con) or ICI $182,780(100 \mathrm{nM})$ followed by addition of TNF $\alpha(10 \mathrm{ng} / \mathrm{ml})$ for $48 \mathrm{~h}$ and harvested for viability assay. Asterisk denotes statistical significance from vector control $(p<0.05)$. All data are the means and standard errors of double treatments from a single experiment, and are representative of at least two independent experiments. (C) MCF-7 cells were transfected with $500 \mathrm{ng}$ of empty vector (Vec) or constitutive active AKT (AKT-CA) along with a pEGFP expression vector $(100 \mathrm{ng})$. Cells were treated with vehicle control (Con) or ICI 182,780 (100 nM), followed by the addition of vehicle or TNF- $\alpha(10 \mathrm{ng} / \mathrm{ml})$ and analyzed for cell death by fluorescence microscopy $24 \mathrm{~h}$ later.

(mRNA) via a transcriptional mechanism (24), we investigated the roles of AKT and ER in the regulation of Bcl-2 expression. In contrast to previous results, our initial reporter-based
A

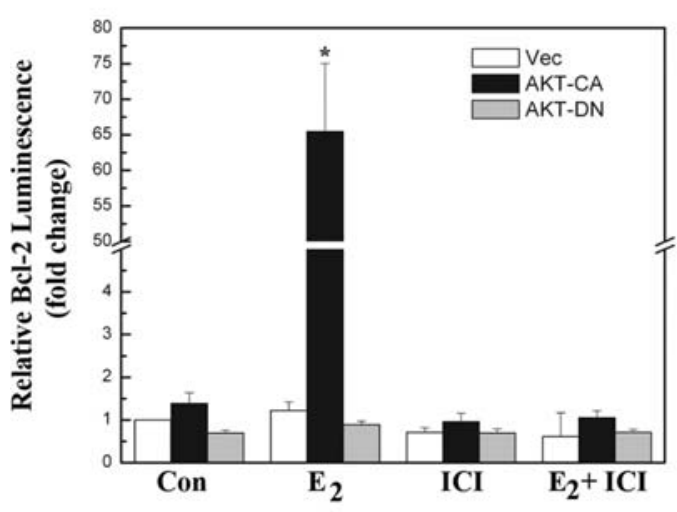

B

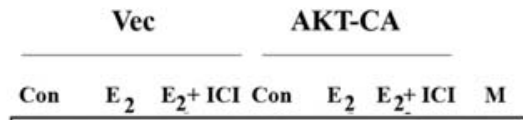

Bcl-2
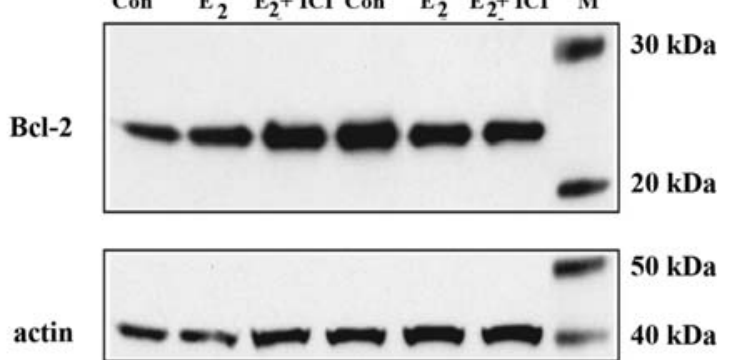

$50 \mathrm{kDa}$

$40 \mathrm{kDa}$

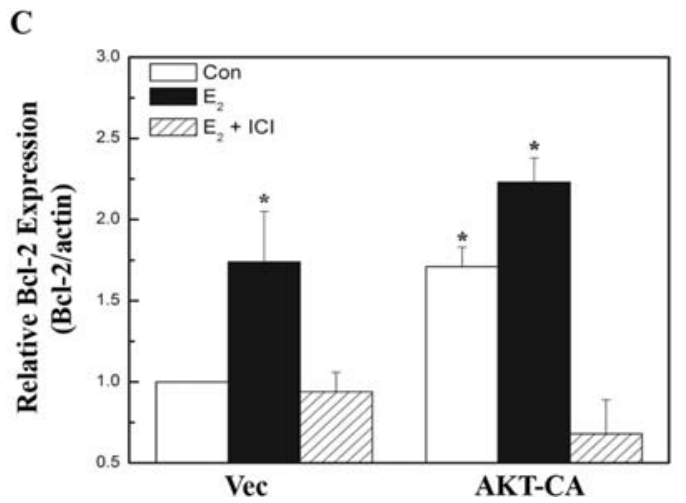

Figure 2. The ER is required for potentiation of Bcl-2 expression by AKT. (A) MCF-7 cells were transfected with the pBcl-2-Luc reporter (200 ng) along with $300 \mathrm{ng}$ empty vector ( $\mathrm{Vec})$, constitutive active AKT (AKT-CA), or dominant negative AKT (AKT-DN). Cells were treated with $\mathrm{E}_{2}(1 \mathrm{nM})$, ICI 182,780 $(100 \mathrm{nM})$, or $\mathrm{E}_{2}+\mathrm{ICI}$ and were harvested $24 \mathrm{~h}$ later and assayed for luciferase activity. Data are represented as fold change normalized to vehicle-treated Vec control, and the values are the means and standard errors of double treatments from a single experiment, and representative of at least two independent experiments. Asterisk denotes statistical significance from vector control $(\mathrm{p}<0.05)$. (B) MCF-7 cells were transfected with $5 \mu \mathrm{g}$ empty vector $(\mathrm{Vec})$ or constitutive active AKT (AKT-CA) and were treated with vehicle control (Con) or $\mathrm{E}_{2}(1 \mathrm{nM})$ with or without ICI 182,780 $(100 \mathrm{nM})$, and harvested $24 \mathrm{~h}$ later. Fifty micrograms whole cell extracts were subjected to Western blot analysis using a Bcl-2 antibody. The blots were then stripped and re-probed with an actin antibody as an internal loading control. Data are represented as Bcl-2 protein level relative to actin (Bcl2/actin) and normalized to vehicle-treated Vec control. The blot shown is representative of at least three independent experiments. (C) Densitometry of Western blot analysis from 2B. Asterisk denotes statistical significance from vector control $(\mathrm{p}<0.05)$.

luciferase assays of the full-length Bcl-2 promoter reveal that $\mathrm{E}_{2}$ alone did not induce significant $\mathrm{Bcl}-2$ promoter activation (Fig. 2A). Differences in promoter regions may contribute to 
A

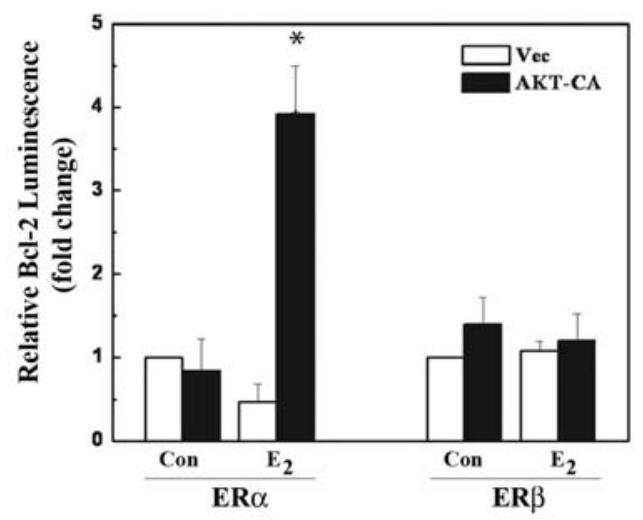

C

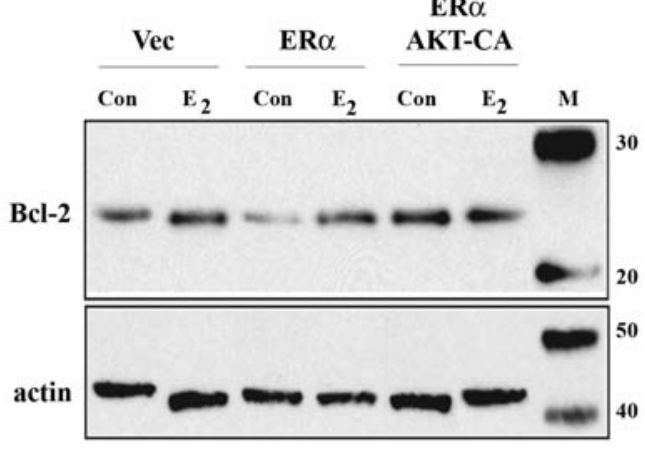

B

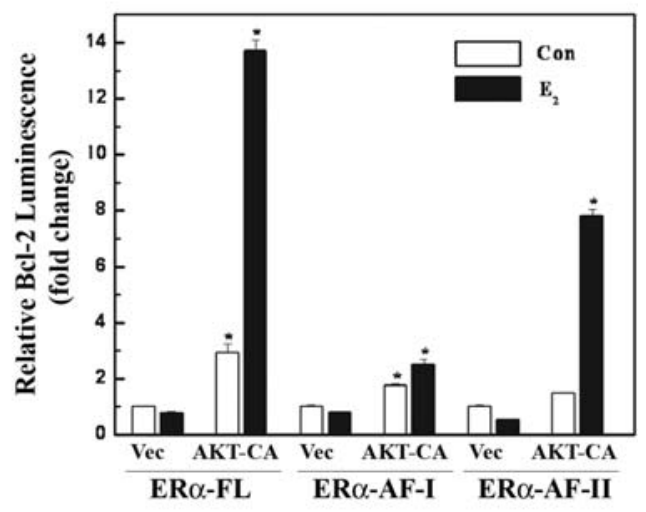

D

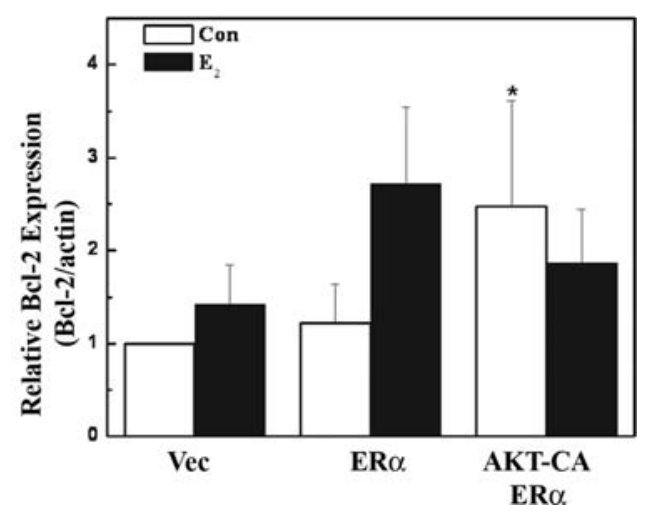

Figure 3. AKT differentially potentiates ER $\alpha$ and ERß activity at the Bcl-2 promoter. (A) HEK 293 cells were transfected with the pBcl-2-Luc reporter (200 ng), along with $300 \mathrm{ng}$ empty vector (Vec) or constitutive active AKT (AKT-CA), along with either $100 \mathrm{ng}$ ER $\alpha$ or ERß. Cells were treated with vehicle control $(V e h)$ or $E_{2}(1 \mathrm{nM})$ and were harvested after $24 \mathrm{~h}$ of treatment and assayed for luciferase activity. Data are represented as RLUs normalized to vehicle-treated Vec control, and the values are the means and standard errors of double treatments from a single experiment and are representative of at least two independent experiments. Asterisk denotes statistical significance from vector control $(\mathrm{p}<0.05)$. (B) HEK 293 cells were transfected as in (A) with the addition of ER domain mutants ER $\alpha$-AF-I and ER-AF-II. The experiment was carried out as in (A). Asterisk denotes statistical significance from vector control of each ER construct ( $\mathrm{p}<0.05)$. (C) HEK 293 cells were transfected with a total of $5 \mu \mathrm{g}$ DNA of empty vector (Vec) or ER $\alpha$, with or without constitutive active AKT (AKT-CA) and were treated with vehicle control (Con) or $\mathrm{E}_{2}(1 \mathrm{nM})$, and harvested $24 \mathrm{~h}$ later. Whole cell extracts $(50 \mu \mathrm{g})$ were subjected to Western blot analysis using Bcl-2 antibody. The blots were then stripped and re-probed with actin antibody as an internal loading control. Data are represented as Bcl-2 protein level relative to actin (Bc12/actin) and normalized to vehicle-treated Vec control. (D) Densitometry of the Western blot analysis from E. The blot shown is representative and the data are the results of at least three independent experiments. Asterisk denotes statistical significance from vector control $(\mathrm{p}<0.05)$.

these variations, as our $\mathrm{Bcl}-2$ reporter construct i) lacks the estrogen responsive elements located within the coding region of the gene that is required for $\mathrm{E}_{2}$ induction of $\mathrm{Bcl}-2$ promoter activity (29), and ii) contains $\pi 1$ binding sites that have been shown to negatively regulate $\mathrm{Bcl}-2$ expression in reporter gene assays (54). More importantly, our results indicate that in the presence of $1 \mathrm{nM} \mathrm{E}$, AKT-CA potentiated Bcl-2 expression by 54-fold over Vec (Fig. 2A). Additionally, ICI 182,780 abolished this Bcl-2 upregulation, demonstrating that the ER was required for transcriptional activation of the $\mathrm{Bcl}-2$ promoter by AKT.

Immunoblot analysis was used to determine whether upregulation of the $\mathrm{Bcl}-2$ promoter translates into greater protein production. Previous studies exploring AKT regulation of Bcl-2 focused on the ability of this kinase to activate the Bcl-2 promoter region with reporter assays $(26,27)$, and Western blot analyses did not account for loading controls
(34). Compared to untreated vector control, $\mathrm{E}_{2}(1 \mathrm{nM})$ expectedly enhanced $\mathrm{Bcl}-2$ protein levels, and AKT-CA increased Bcl-2 expression even further (Fig. 2B and C). AKT-CA enhanced ligand-independent expression of $\mathrm{Bcl}-2$, perhaps not surprisingly since peptide growth factor (PGF) signaling itself can increase Bcl-2 expression $(26,27)$. More importantly, both $\mathrm{E}_{2}$ and $\mathrm{AKT}-\mathrm{CA}$ upregulation of $\mathrm{Bcl}-2$ protein was blocked by ICI 182,780, again demonstrating a requirement for the ER. These results reveal that transcriptional upregulation of the Bcl-2 pro-survival gene may be one of the mechanisms by which the ER and AKT cooperate to enhance cell survival.

AKT potentiates Bcl-2 expression through ERa. Even though $\mathrm{ER} \alpha$ and $\mathrm{ER} \beta$ are co-expressed in mammary tissues and breast carcinomas (55), the two receptors are differentially influenced by growth factor signaling (56). To determine the specificity of 
A

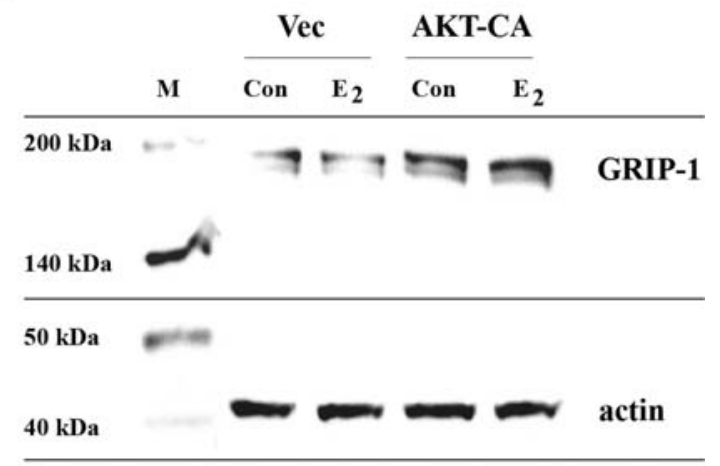

B

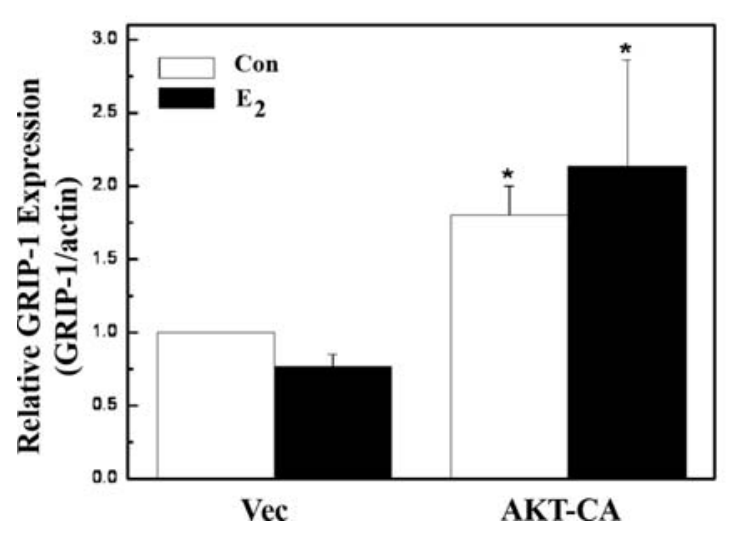

Figure 4. AKT enhances GRIP1 protein expression. (A) MCF-7 cells were transfected with $5 \mu \mathrm{g}$ empty vector (Vec) or constitutive active AKT (AKT$\mathrm{CA})$ and were treated with either vehicle (con) or $\mathrm{E}_{2}(1 \mathrm{nM})$ for $24 \mathrm{~h}$. Once harvested, $50 \mu \mathrm{g}$ whole cell extracts were subjected to Western blot analysis using a GRIP1 antibody. The blots were then stripped and re-probed with an actin antibody as an internal loading control. (B) Densitometry of the Western blot analysis. Data are represented as GRIP1 protein level relative to actin (GRIP1/actin) and are normalized to vehicle-treated Vec control and are the results of three independent experiments. Asterisk denotes statistical significance from vector control $(\mathrm{p}<0.05)$.

PI3K-AKT crosstalk with each ER ( $\alpha$ or $\beta$ ), human embryonic kidney (HEK) 293 cells lacking both ER $\alpha$ and ERß were used (49). Since our earlier results suggest a requirement for the ER in Bcl-2 promoter activation, similar experiments were used to determine the involvement of ER $\alpha$ and ERß. In the presence of $\mathrm{E}_{2}(1 \mathrm{nM})$, AKT potentiation of $\mathrm{Bcl}-2$ promoter activation was shown to require ER $\alpha$ but not ERß (Fig. 3A). Although ER $\alpha$ potentiated Bcl-2 reporter activity by 5 -fold over Vec alone, this increase was much less than the 54-fold potentiation observed in Fig. 2A, suggesting that both ERs may be required for the robust potentiation seen in the MCF-7 cells that contain both ER isoforms.

$\mathrm{ER} \alpha$ contains two activation function domains (AF-I and AF-II) that recruit coactivator proteins and are responsible for the transcriptional activities of the receptor. Here, expression vectors for ER $\alpha$ that have been mutated to functionally lack either $\mathrm{AF}$ domain were used to examine the specificity of AKT potentiation of ER $\alpha$ activity. AKT-CA potentiated $\mathrm{Bcl}-2$ expression through the full-length $\mathrm{ER} \alpha$, the ER $\alpha-\mathrm{AF}-\mathrm{I}$ and AF-II domains, indicating that AKT-CA may target both
A

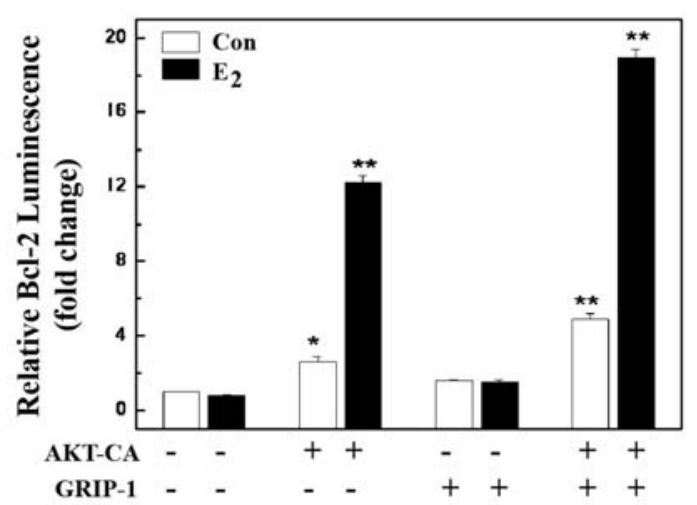

B

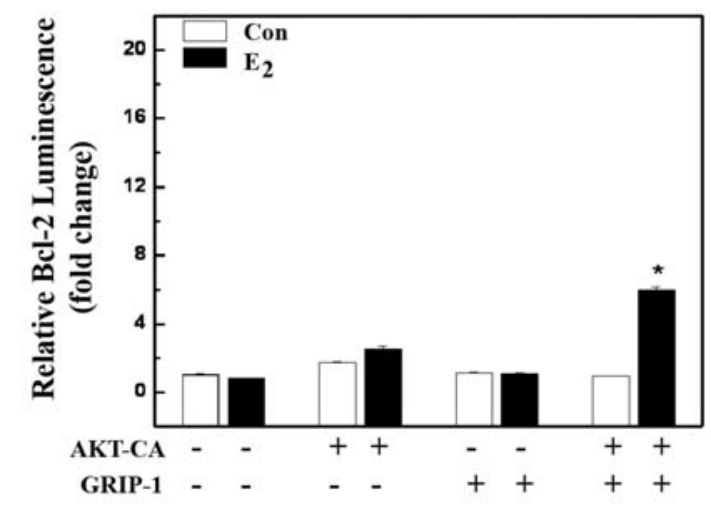

C

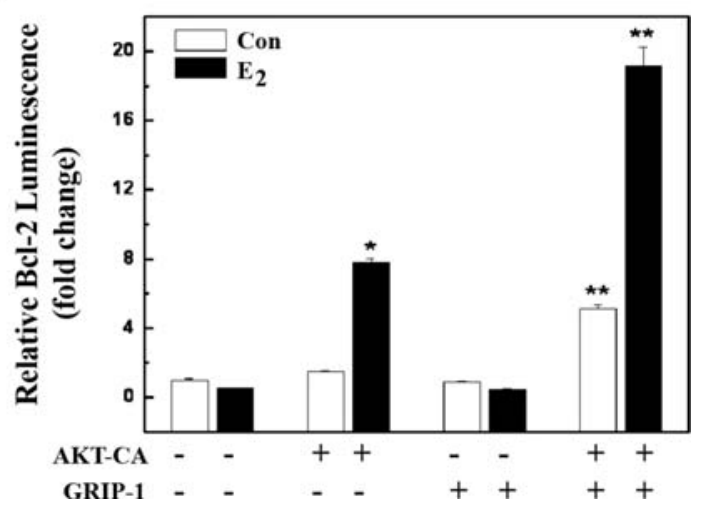

Figure 5. AKT and GRIP1 cooperatively enhance ER $\alpha$-mediated Bcl-2 promoter activation. (A) HEK 293 cells were transfected with a pBcl-2-Luc reporter, along with constitutive active AKT (AKT-CA) or GRIP1 and ER $\alpha$ (full length). Cells were treated with vehicle control (Con) or $\mathrm{E}_{2}(1 \mathrm{nM})$ and were harvested after $24 \mathrm{~h}$ of treatment for measurement of luciferase activity. Data are represented as fold change and are normalized to vehicle-treated Vec control. All the values are the means and standard errors of double treatments from a single experiment, and are representative of at least two independent experiments. Asterisk denotes statistical significance from vector control cells. Two asterisks denotes statistical significance from AKT-CA control cells. (B) Experimental design the same as in (A) except ER-AF-I domain mutant was used. (C) Experimental design the same as in (A) except ER-AF-II domain mutant was used.

activation domains of ER $\alpha$ (Fig. 3B). AKT-CA potentiated Bcl-2 expression to the highest levels through the full-length $\mathrm{ER} \alpha$. Since the AF-I and AF-II domains synergize for maximal ER transcriptional activity (15), the ability of AKT to target both $\mathrm{AF}$ domains of the $\mathrm{ER} \alpha$ is likely necessary for maximal potentiation of Bcl-2 expression. 
A

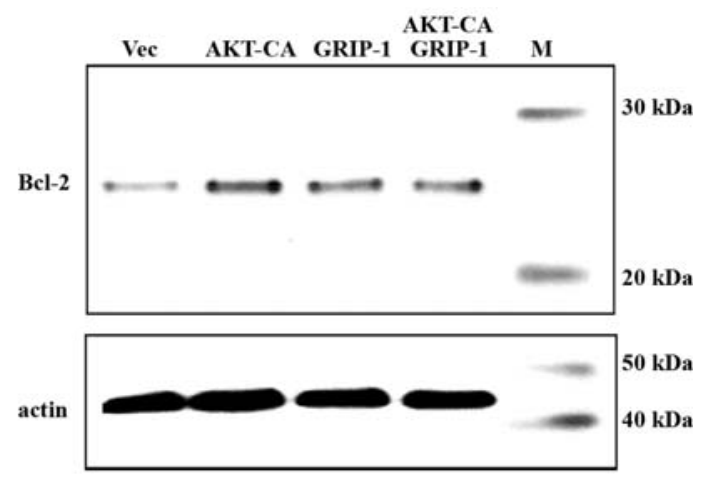

B

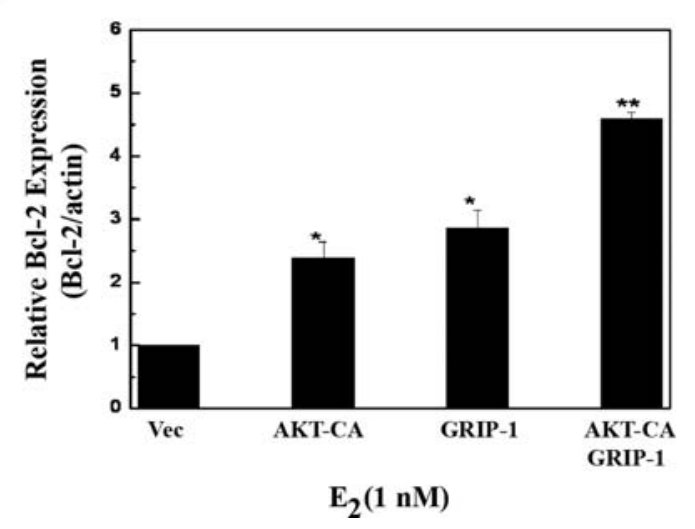

Figure 6. AKT and GRIP1 cooperatively enhance Bcl-2 protein expression. (A) MCF-7 cells were transfected with $5 \mu \mathrm{g}$ vector control (Vec), constitutive active AKT (AKT-CA), pSG5-GRIP1-HA (GRIP1), or $2.5 \mu \mathrm{g}$ each AKT-CA and GRIP1. Cells were treated with $\mathrm{E}_{2}(1 \mathrm{nM})$ for $24 \mathrm{~h}$ prior to harvesting. Whole cell extracts $(50 \mu \mathrm{g})$ were subjected to Western blot analysis using a Bcl-2 antibody. The blots were then stripped and re-probed with an actin antibody as an internal loading control. (B) Densitometry of the Western blot analysis. Data are represented as Bcl-2 protein level relative to actin (Bcl2/actin) and are normalized to vector control. Data are the results of two independent experiments. Asterisk denotes statistical significance from vector $\mathrm{E}_{2}$, and two asterisks denotes statistical significance from AKTCA $\mathrm{E}_{2}$ and GRIP-1 $\mathrm{E}_{2}(\mathrm{p}<0.05)$.

To confirm the crosstalk between ER $\alpha$ and AKT leads to an increase in Bcl-2 protein levels, Western blot analyses were performed in HEK 293 cells transfected with AKT-CA and $\mathrm{ER} \alpha$ (Fig. $3 \mathrm{C}$ and D). $\mathrm{E}_{2}(1 \mathrm{nM})$ induction of $\mathrm{Bcl}-2$ protein expression was enhanced with $\mathrm{ER} \alpha$, although the increase was not significant compared to vector control cells. In these cells containing only ER $\alpha$, AKT-CA did potentiate Bcl-2 protein expression in the absence of $\mathrm{E}_{2}$ (Fig. 3D), as seen in Fig. 2C. However, the presence of $\mathrm{E}_{2}$ had little effect on Bcl-2 expression. Because these cells do not contain ERß, Bcl-2 potentiation may not be maximized. Collectively, our results suggest that AKT regulation of cell survival decisions require $\mathrm{ER} \alpha$, although the ERß may also be important.

AKT increases GRIP1 protein expression. Coactivators are integral components in ER-mediated transcriptional signaling (10). Here, we investigated AKT regulation of GRIP-1 protein levels using immunoblot analyses of MCF-7 cells (Fig. 4A and $\mathrm{B}$ ). $\mathrm{E}_{2}$ alone was not able to enhance GRIP-1 protein expression in vector control cells. However, AKT-CA did enhance GRIP-1 protein expression by 1.8 -fold and by 2.14-fold in the presence of $1 \mathrm{nM} \mathrm{E}_{2}$. These results suggest that AKT plays a role in expression of the coactivator GRIP-1.

AKT and GRIP-1 cooperatively enhance Bcl-2 expression. Since AKT was able to enhance GRIP-1 protein expression, we investigated the possibility that GRIP-1 may potentiate $\mathrm{Bcl}-2$ expression in the presence of $\mathrm{E}_{2}$. As previously shown, AKT-CA alone was able to potentiate $\mathrm{Bcl}-2$ expression through $\mathrm{ER} \alpha$ (Fig. 3B and C). Overexpression of GRIP-1 alone was not able to achieve this potentiation (Fig. 5A). However, AKT-CA and GRIP-1 potentiated Bcl-2 expression to higher levels than either factor alone. This potentiation is seen with all ER $\alpha$ constructs, although the effects were lowest with the AF-I mutant (Fig. 5B) and highest with the full-length (Fig. 5A). Collectively, these data suggest that AKT-CA and GRIP-1 together may preferentially target the AF-II domain to potentiate $\mathrm{Bcl}-2$ expression.

To determine whether AKT-CA and GRIP1 potentiate $\mathrm{Bcl}-2$ protein expression in the presence of $\mathrm{E}_{2}$, we used immunoblot analyses. Both AKT-CA and GRIP-1 were able to potentiate $\mathrm{Bcl}-2$ protein expression to similar levels, but not significantly different from vector (data not shown). However, in the presence of $\mathrm{E}_{2}$, AKT-CA and GRIP-1 together were able to significantly enhance $\mathrm{Bcl}-2$ protein expression to a greater level than either factor alone (Fig. 6A and B), suggesting that these two factors may cooperate to transcriptionally activate the $\mathrm{Bcl}-2$ promoter region.

\section{Discussion}

Crosstalk between the ER- $\mathrm{E}_{2}$ and the IGF1-PI3K-AKT signaling pathways has been shown to promote cancer cell survival. While growth factor signaling pathways have been shown to activate the ER, the precise role of the receptor in this survival crosstalk remains unclear. Previously, Campbell et al demonstrated the ability of AKT to rescue cells from apoptosis induced by the chemotherapeutic drug tamoxifen (34). However, since tamoxifen is an ER antagonist (57), the contribution of ER to AKT-induced cell survival could not be completely assessed. Indeed, Campbell's studies suggest that AKT survival mechanisms may be ER-independent. Recently, Boland's group demonstrated that $\mathrm{E}_{2}$ may protect murine skeletal muscle cells from $\mathrm{H}_{2} \mathrm{O}_{2}$-induced apoptosis through $\mathrm{ER} \alpha$ and ERß, possibly involving PI3K/AKT signaling (58). Our studies with a physiological inducer of apoptosis, $\mathrm{TNF} \alpha$ (43), reveal that the ER is required for AKT-mediated cell survival in breast carcinoma cells (Fig. 1B), suggesting that the PI3K-AKT and ER-E $\mathrm{E}_{2}$ signaling pathways converge to regulate cell survival decisions.

The ER's ability to regulate transcription of target genes, such as Bcl-2, has been linked to its ability to protect breast cancer cells from $\mathrm{TNF} \alpha$-induced apoptosis $(24,53)$. Here, we show that ER $\alpha$, both AF-I and AF-II domains, is targeted by AKT to bring about potentiation of Bcl-2 expression at both the transcriptional and translational levels (Figs. 2 and 3). These results re-enforce the role of the ER $\alpha$ as a mediator of cell survival in vitro (59) and in vivo (60). Even though ERß was 
not able to activate the Bcl-2 promoter in response to AKT, this receptor isoform may play a secondary supportive role, since AKT was able to potentiate Bcl-2 promoter activity much more potently in cells containing both receptor isoforms (MCF-7) than in cells with only ERa (HEK 293). Recently, we showed that ERß is targeted by AKT signaling (21), as demonstrated by the ability of AKT to potentiate ERß transcriptional activity at a consensus ERE promoter. Hence, AKT regulation of ERß function in cell survival decisions may be more important in cells or tissues where ERß expression predominates, such as in the prostate (55).

The exact role of the ER at the Bcl-2 promoter remains to be determined. Since the ER is involved in both long-term transcriptional regulation of genes (genomic effects) $(61,62)$ and in immediate cytoplasmic signaling events (non-genomic effects) (63-67), these two functions of the ER may converge at the Bcl-2 promoter. The ER- $\mathrm{E}_{2}$ complex upregulates Bcl-2 expression either directly by acting on EREs located within the coding region of the gene (29) or indirectly through interaction with the $\mathrm{Sp} 1$ protein (28). In addition, the ER may also complex with components of cytoplasmic signaling pathways, such as PI3K (68).

Previously, we showed that the overexpression of coactivators may provide a survival advantage to breast carcinoma cells in the presence of $\mathrm{TNF} \alpha$ (69). Other researchers have found that the coactivator PELP1 may affect breast cancer cell sensitivity to apoptosis induced by TNF $\alpha$ (70). Here, we show for the first time the ability of AKT to upreguate GRIP-1 protein expression (Fig. 4) and the cooperation between AKT and GRIP-1 to enhance Bcl-2 transcriptional and protein expression to levels higher than either factor alone (Fig. 5). These results suggest that AKT potentiation of the Bcl-2 promoter region may result from AKT's ability to regulate both ER $\alpha$ and factors that interact with the receptor, such as GRIP-1. Once expressed, GRIP-1 may cooperate with AKT to enhance $\mathrm{ER} \alpha$ activity in order to potentiate $\mathrm{Bcl}-2$ expression. Other investigators have demonstrated that the coactivator amplified in breast cancer 1 (AIB1/SRC-3) is required for $\mathrm{Bcl}-2$ expression. However, these investigators suggested that the regulation of $\mathrm{Bcl}-2$ protein expression occurs independently of the ER (71). It is possible that GRIP-1 and AIB1 may affect the ER differentially at the Bcl-2 promoter.

Both the ER-E $E_{2}$ and PI3K-AKT signaling pathways have been shown to independently protect breast cancer cells from apoptosis induced by $\mathrm{TNF} \alpha(44,50,72)$. In this study, we provide evidence that a survival crosstalk between the ER-E $\mathrm{E}_{2}$ and PI3K-AKT pathways protects breast carcinoma cells from $\mathrm{TNF} \alpha$-induced apoptosis. Given the importance of $\mathrm{TNF} \alpha$ in cell survival regulation of both normal and malignant breast tissue $(39,40)$, the ability of a survival crosstalk to enhance cell survival may lead to cancer development. A growing area of research explores the potential of $\mathrm{TNF} \alpha$ and its family members in cancer therapy (73-77). Hence, molecular studies of survival crosstalk that compromise the apoptotic effects of TNF $\alpha$ may prove therapeutically useful (36).

\section{Acknowledgements}

This study was supported by the US Department of Energy Grant DE-FC2000NT40843 (to J.A.M.), the National Institute of Diabetes and Digestive and Kidney Diseases Grant 5R01DK059389-06 (to M.E.B.), Department of Health and Human Services Center for Disease Control Grant R06/ CCR419466-02 (to J.A.M.), US Department of Defense Breast Cancer Research Program DAMD-17-02-1-0596 (to M.E.B.), NIH Grant 1 T32 CA65436-01A3 (to C.B.W.), the Cancer Association of Greater New Orleans (to B.S.B.), the TulaneXavier Center for Bioenvironmental Research (to J.A.M., M.E.B.) and the Louisiana Cancer Research Consortium (M.R.B.)

\section{References}

1. Kumar R, Vadlamudi RK and Adam L: Apoptosis in mammary gland and cancer. Endocr Relat Cancer 7: 257-269, 2000.

2. Green DR and Evan GI: A matter of life and death. Cancer Cell 1: 19-30, 2002.

3. Imagawa W, Pedchenko VK, Helber J and Zhang H: Hormone/ growth factor interactions mediating epithelial/stromal communication in mammary gland development and carcinogenesis. J Steroid Biochem Mol Biol 80: 213-230, 2002.

4. Feigelson HS and Henderson BE: Estrogens and breast cancer. Carcinogenesis 17: 2279-2284, 1996.

5. Gross JM and Yee D: The type-1 insulin-like growth factor receptor tyrosine kinase and breast cancer: Biology and therapeutic relevance. Cancer Metastasis Rev 22: 327-336, 2003.

6. Dufourny B, Alblas J, van Teeffelen HAAM, et al: Mitogenic signaling of insulin-like growth factor i in mcf-7 human breast cancer cells requires phosphatidylinositol 3-kinase and is independent of mitogen-activated protein kinase. J Biol Chem 272: 31163-31171, 1997.

7. Dudek H, Datta SR, Franke TF, et al: Regulation of neuronal survival by the serine-threonine protein kinase akt. Science 275: 661-665, 1997.

8. Nilsson S, Makela S, Treuter E, et al: Mechanisms of estrogen action. Physiol Rev 81: 1535-1565, 2001.

9. White R and Parker MG: Molecular mechanisms of steroid hormone action. Endocr Relat Cancer 5: 1-14, 1998.

10. McKenna NJ and O'Malley BW: Combinatorial control of gene expression by nuclear receptors and coregulators. Cell 108: 465-474, 2002.

11. Cavarretta ITR, Mukopadhyay R, Lonard DM, et al: Reduction of coactivator expression by antisense oligodeoxynucleotides inhibits ERalpha transcriptional activity and mcf-7 proliferation. Mol Endocrinol 16: 253-270, 2002.

12. Voegel JJ, Heine MJ, Zechel C, Chambon P and Gronemeyer H: TIF2, a $160 \mathrm{kda}$ transcriptional mediator for the ligand-dependent activation function AF-2 of nuclear receptors. EMBO J 15: 3667-3675, 1996.

13. Hong H, Kohli K, Garabedian M and Stallcup M: GRIP1, a transcriptional coactivator for the AF-2 transactivation domain of steroid, thyroid, retinoid, and vitamin D receptors. Mol Cell Biol 17: 2735-2744, 1997.

14. Webb P, Nguyen P, Shinsako J, et al: Estrogen receptor activation function 1 works by binding p160 coactivator proteins. Mol Endocrinol 12: 1605-1618, 1998.

15. Benecke A, Chambon P and Gronemeyer H: Synergy between estrogen receptor alpha activation functions AF1 and AF2 mediated by transcription intermediary factor TIF2. EMBO Rep 1: 151-157, 2000 .

16. Anzick SL, Kononen J, Walker RL, et al: AIB1, a steroid receptor coactivator amplified in breast and ovarian cancer. Science 277: 965-968, 1997.

17. Kurebayashi J, Otsuki T, Kunisue H, Tanaka K, Yamamoto S and Sonoo H: Expression levels of estrogen receptor-alpha, estrogen receptor-beta, coactivators, and corepressors in breast cancer. Clin Cancer Res 6: 512-518, 2000.

18. Hudelist G, Czerwenka K, Kubista E, Marton E, Pischinger K and Singer CF: Expression of sex steroid receptors and their co-factors in normal and malignant breast tissue: AIB1 is a carcinoma-specific co-activator. Breast Cancer Res Treat 78: 193-204, 2003.

19. Font de Mora J and Brown M: AIB1 is a conduit for kinasemediated growth factor signaling to the estrogen receptor. Mol Cell Biol 20: 5041-5047, 2000. 
20. Lopez GN, Turck CW, Schaufele F, Stallcup MR and Kushner PJ: Growth factors signal to steroid receptors through mitogenactivated protein kinase regulation of p160 coactivator activity. J Biol Chem 276: 22177-22182, 2001 .

21. Duong BN, Elliott S, Frigo DE, et al: Akt regulation of estrogen receptor beta transcriptional activity in breast cancer. Cancer Res 66: 8373-8381, 2006.

22. Teixeira C, Reed JC and Pratt MA: Estrogen promotes chemotherapeutic drug resistance by a mechanism involving Bcl-2 proto-oncogene expression in human breast cancer cells. Cancer Res 55: 3902-3907, 1995.

23. Burow ME, Tang Y, Collins-Burow BM, et al: Effects of environmental estrogens on tumor necrosis factor alpha-mediated apoptosis in MCF-7 cells. Carcinogenesis 20: 2057-2061, 1999.

24. Gompel A, Somai S, Chaouat M, et al: Hormonal regulation of apoptosis in breast cells and tissues. Steroids 65: 593-598, 2000

25. Singleton JR, Dixit VM and Feldman EL: Type I insulin-like growth factor receptor activation regulates apoptotic proteins. J Biol Chem 271: 31791-31794, 1996.

26. Pugazhenthi S, Miller E, Sable C, et al: Insulin-like growth factor-I induces Bcl-2 promoter through the transcription factor cAMP-response element-binding protein. J Biol Chem 274: 27529-27535, 1999.

27. Pugazhenthi S, Nesterova A, Sable C, et al: Akt/protein kinase B up-regulates Bcl-2 expression through cAMP-response elementbinding protein. J Biol Chem 275: 10761-10766, 2000.

28. Dong L, Wang W, Wang F, et al: Mechanisms of transcriptional activation of $\mathrm{Bcl}-2$ gene expression by 17 beta-estradiol in breast cancer cells. J Biol Chem 274: 32099-32107, 1999.

29. Perillo B, Sasso A, Abbondanza C and Palumbo G: 17betaestradiol inhibits apoptosis in MCF-7 cells, inducing Bcl-2 expression via two estrogen-responsive elements present in the coding sequence. Mol Cell Biol 20: 2890-2901, 2000

30. Safe S: Transcriptional activation of genes by 17 beta-estradiol through estrogen receptor-SP1 interactions. Vitam Horm 62: 231-252, 2001

31. Martin MB, Franke TF, Stoica GE, et al: A role for AKT in mediating the estrogenic functions of epidermal growth factor and insulin-like growth factor I. Endocrinology 141: 4503-4511, 2000

32. Klotz DM, Hewitt SC, Ciana P, et al: Requirement of estrogen receptor-alpha in insulin-like growth factor-I (IGF-I)-induced uterine responses and in vivo evidence for insulin-like growth factor-I/estrogen receptor cross-talk. J Biol Chem 277: 8531-8537, 2002.

33. Stoica GE, Franke TF, Wellstein A, et al: Estradiol rapidly activates AKT via the erbB2 signaling pathway. Mol Endocrinol 17: 818-830, 2003

34. Campbell RA, Bhat-Nakshatri P, Patel NM, Constantinidou D, Ali $\mathrm{S}$ and Nakshatri H: Pi3 kinase/AKT-mediated activation of estrogen receptor alpha: A new model for anti-estrogen resistance. J Biol Chem 276: 9817-9824, 2001.

35. Ahmad S, Singh N and Glazer RI: Role of AKT1 in 17betaestradiol- and insulin-like growth factor I (IGF-I)-dependent proliferation and prevention of apoptosis in MCF-7 breast carcinoma cells. Biochem Pharmacol 58: 425-430, 1999.

36. Aggarwal BB: Signalling pathways of the TNF superfamily: A double-edged sword. Nat Rev Immunol 3: 745-756, 2003.

37. Basolo F, Calvo S, Fiore L, et al: Production of cytokines and response to them in normal and transformed human mammary epithelial cells. Ann N Y Acad Sci 698: 126-130, 1993.

38. Pusztai L, Clover LM, Cooper K, Starkey PM, Lewis CE and McGee JO: Expression of tumour necrosis factor alpha and its receptors in carcinoma of the breast. Br J Cancer 70: 289-292, 1994

39. Sohn BH, Moon HB, Kim TY, et al: Interleukin-10 up-regulates tumour-necrosis-factor-alpha-related apoptosis-inducing ligand (TRAIL) gene expression in mammary epithelial cells at the involution stage. Biochem J 360: 31-38, 2001

40. Bellomo G, Perotti M, Taddei F, et al: Tumor necrosis factor alpha induces apoptosis in mammary adenocarcinoma cells by an increase in intranuclear free $\mathrm{Ca}^{2+}$ concentration and DNA fragmentation. Cancer Res 52: 1342-1346, 1992.

41. Jaattela M, Benedict M, Tewari M, Shayman JA and Dixit VM $\mathrm{Bcl}-\mathrm{x}$ and Bcl-2 inhibit tnf and Fas-induced apoptosis and activation of phospholipase A2 in breast carcinoma cells. Oncogene 10: 2297-2305, 1995.

42. Szlosarek PW and Balkwill FR: Tumor necrosis factor alpha: A potential target for the therapy of solid tumors. Lancet 4: 565-573, 2003.
43. Burow ME, Weldon CB, Tang Y, et al: Differences in susceptibility to tumor necrosis factor alpha-induced apoptosis among MCF-7 breast cancer cell variants. Cancer Res 58: 4940-4946, 1998.

44. Burow ME, Weldon CB, Collins-Burow BM, et al: Cross-talk between phosphatidylinositol 3-kinase and sphingomyelinase pathways as a mechanism for cell survival/death decisions. J Biol Chem 275: 9628-9635, 2000.

45. Burow ME, Boue SM, Collins-Burow BM, et al: Phytochemical glyceollins, isolated from soy, mediate antihormonal effects through estrogen receptor alpha and beta. J Clin Endocrinol Metab 86: 1750-1758, 2001.

46. Hall JM and McDonnell DP: The estrogen receptor betaisoform (ERbeta) of the human estrogen receptor modulates ERalpha transcriptional activity and is a key regulator of the cellular response to estrogens and antiestrogens. Endocrinology 140: 5566-5578, 1999

47. Wilson BE, Mochon E and Boxer LM: Induction of Bcl-2 expression by phosphorylated creb proteins during B-cell activation and rescue from apoptosis. Mol Cell Biol 16: 5546-5556, 1996.

48. Burow ME, Weldon CB, Chiang TC, et al: Differences in protein kinase $\mathrm{c}$ and estrogen receptor alpha, beta expression and signaling correlate with apoptotic sensitivity of MCF-7 breast cancer cell variants. Int J Oncol 16: 1179-1187, 2000.

49. Kuiper GG, Lemmen JG, Carlsson B, et al: Interaction of estrogenic chemicals and phytoestrogens with estrogen receptor beta. Endocrinology 139: 4252-4263, 1998.

50. Burow ME, Weldon CB, Melnik LI, et al: Pi3-K/AKT regulation of NF-kappaB signaling events in suppression of TNF-induced apoptosis. Biochem Biophys Res Commun 271: $342-345,2000$

51. Nicholson RI and Johnston SR: Endocrine therapy - current benefits and limitations. Breast Cancer Res Treat 93 (Suppl. 1): S3-S10, 2005.

52. Henson ES and Gibson SB: Surviving cell death through epidermal growth factor (EGF) signal transduction pathways: Implications for cancer therapy. Cell Signal 18: 2089-2097, 2006.

53. Newton CJ: Estrogen receptor blockade by the pure antiestrogen, ZM 182780, induces death of pituitary tumour cells. J Steroid Biochem Mol Biol 55: 327-336, 1995.

54. Chen $\mathrm{H}$ and Boxer L: Pi1 binding sites are negative regulators of Bcl-2 expression in pre-B cells. Mol Cell Biol 15: 38403847,1995

55. Couse JF, Lindzey J, Grandien K, Gustafsson JA and Korach KS: Tissue distribution and quantitative analysis of estrogen receptoralpha (ERalpha) and estrogen receptor-beta (ERbeta) messenger ribonucleic acid in the wild-type and ERalpha-knockout mouse. Endocrinology 138: 4613-4621, 1997.

56. Wade CB, Robinson S, Shapiro RA and Dorsa DM: Estrogen receptor (ER) $\alpha$ and ER $\beta$ exhibit unique pharmacologic properties when coupled to activation of the mitogen-activated protein kinase pathway. Endocrinology 142: 2336-2342, 2001.

57. Borgna JL and Rochefort H: Hydroxylated metabolites of tamoxifen are formed in vivo and bound to estrogen receptor in target tissues. J Biol Chem 256: 859-868, 1981.

58. Vasconsuelo A, Milanesi L and Boland R: 17beta-estradiol abrogates apoptosis in murine skeletal muscle cells through estrogen receptors: Role of the phosphatidylinositol 3kinase/AKT pathway. J Endocrinol 196: 385-397, 2008.

59. Hisamoto K, Ohmichi M, Kanda Y, et al: Induction of endothelial nitric oxide synthase phosphorylation by the raloxifene analog Ly 117018 is differentially mediated by AKT and extracellular signal-regulated protein kinase in vascular endothelial cells. J Biol Chem 276: 47642-47649, 2001.

60. D'Astous M, Mendez P, Morissette M, Garcia-Segura LM and Di Paolo T: Implication of the phosphatidylinositol-3 kinase/ protein kinase $\mathrm{B}$ signaling pathway in the neuroprotective effect of estradiol in the striatum of 1-methyl-4-phenyl-1, 2, 3, 6-tetrahydropyridine mice. Mol Pharmacol 69: 1492-1498, 2006.

61. Sanchez R, Nguyen D, Rocha W, White JH and Mader S: Diversity in the mechanisms of gene regulation by estrogen receptors. Bioessays 24: 244-254, 2002.

62. Tsai MJ and O'Malley BW: Molecular mechanisms of action of steroid/thyroid receptor superfamily members. Annu Rev Biochem 63: 451-486, 1994.

63. Wehling M: Specific, nongenomic actions of steroid hormones. Annu Rev Physiol 59: 365-393, 1997. 
64. Chen Z, Yuhanna IS, Galcheva-Gargova Z, Karas RH, Mendelsohn ME and Shaul PW: Estrogen receptor alpha mediates the nongenomic activation of endothelial nitric oxide synthase by estrogen. J Clin Invest 103: 401-406, 1999.

65. Honda K, Sawada H, Kihara T, et al: Phosphatidylinositol 3kinase mediates neuroprotection by estrogen in cultured cortical neurons. J Neurosci Res 60: 321-327, 2000.

66. Honda K, Shimohama S, Sawada H, et al: Nongenomic antiapoptotic signal transduction by estrogen in cultured cortical neurons. J Neurosci Res 64: 466-475, 2001.

67. Segars JH and Driggers PH: Estrogen action and cytoplasmic signaling cascades. Part I: Membrane-associated signaling complexes. Trends Endocrinol Metab 13: 349-354, 2002.

68. Simoncini T, Hafezi-Moghadam A, Brazil DP, Ley K, Chin WW and Liao JK: Interaction of oestrogen receptor with the regulatory subunit of phosphatidylinositol-3-OH kinase. Nature 407: 538-541, 2000

69. Weldon CB, Elliott S, Zhu Y, et al: Regulation of estrogenmediated cell survival and proliferation by p160 coactivators. Surgery 136: 346-354, 2004.

70. Rayala SK, Mascarenhas J, Vadlamudi RK and Kumar R: Altered localization of a coactivator sensitizes breast cancer cells to tumor necrosis factor-induced apoptosis. Mol Cancer Ther 5: 230-237, 2006.

71. Oh A, List HJ, Reiter R, et al: The nuclear receptor coactivator AIB1 mediates insulin-like growth factor I-induced phenotypic changes in human breast cancer cells. Cancer Res 64: 8299-8308, 2004 .
72. Spyridopoulos I, Sullivan AB, Kearney M, Isner JM and Losordo DW: Estrogen-receptor-mediated inhibition of human endothelial cell apoptosis. Estradiol as a survival factor. Circulation 95: 1505-1514, 1997.

73. Lin T, Huang X, Gu J, et al: Long-term tumor-free survival from treatment with the GFP-trail fusion gene expressed from the hTERT promoter in breast cancer cells. Oncogene 21: 8020$8028,2002$.

74. Keane MM, Ettenberg SA, Nau MM, Russell EK and Lipkowitz S: Chemotherapy augments trail-induced apoptosis in breast cell lines. Cancer Res 59: 734-741, 1999.

75. Chinnaiyan AM, Prasad U, Shankar S, et al: Combined effect of tumor necrosis factor-related apoptosis-inducing ligand and ionizing radiation in breast cancer therapy. Proc Natl Acad Sci USA 97: 1754-1759, 2000.

76. Singh TR, Shankar S, Chen X, Asim M and Srivastava RK: Synergistic interactions of chemotherapeutic drugs and tumor necrosis factor-related apoptosis-inducing ligand/APO-2 ligand on apoptosis and on regression of breast carcinoma in vivo. Cancer Res 63: 5390-5400, 2003.

77. Younes A and Kadin ME: Emerging applications of the tumor necrosis factor family of ligands and receptors in cancer therapy. J Clin Oncol 21: 3526-3534, 2003. 